\title{
Frazeologizmy somatyczne z komponentem KREW w szkolnych słownikach frazeologicznych
}

\author{
Somatic Phraseologies with the Component of BLOOD \\ in School Phrasal Dictionaries
}

Summary: The article presents somatic phraseologies with the BLOOD component excerpted from six school phraseological dictionaries. What has been described and evaluated are both the selection of phraseological material, the place of these items in the macrostructure of the dictionaries, the definition of the meaning, and the manners of indicating the phraseology that is marked stylistically. The most frequent defects, inconsistencies in the notation of the phraseologies with the BLOOD component that occur in school phraseological dictionaries have been pointed to.

Key words: school dictionaries, phraseological dictionaries, somatic phraseology, blood

\section{Frazeologia somatyczna}

Zbiór związków frazeologicznych, zawierający komponenty z jednego pola semantycznego - części ciała, nazywamy frazeologia somatyczną (grec. soma 'ciało'), a związek frazeologiczny, którego komponentem jest nazwa części ciała - somatyzmem lub frazeologizmem somatycznym ${ }^{1}$. Językoznawcy wskazują,

${ }^{1}$ A. Krawczyk-Tyrpa: Frazeologia somatyczna w gwarach polskich. Wrocław 1987, s. 25; A. Tyrpa: Frazeologia somatyczna: zwiazki frazeologiczne o znaczeniach motywowanych cechami części ciała w gwarach polskich. Łask 2005, s. 30-31; E. Michow: Z zagadnień frazeologii: związki frazeologiczne zawierające nazwy części ciała. Cz. I. „Język Polski w Szkole dla Klas IV—VIII" 1988/1989, z. 1, s. 82. 
że nazwy części ciała szczególnie często stają się komponentami związków frazeologicznych². Jak zauważa Elżbieta Michow:

Wyrazy takie, jak: oko, ucho, ręka, noga, głowa, język, nos, krew, kości itp. wchodzą w skład wielu wyrażeń i zwrotów³.

Badacze od dawna wskazują, że nazwy części ciała, zwane też nomina anatomica, to jedna z podstawowych grup rzeczowników w każdym języku, o czym świadczy nie tylko ich wysoka frekwencja, ale także zdolność występowania w licznych znaczeniach przenośnych oraz szczególna produktywność słowotwórcza. Badania nad leksyką potoczną Danuty Buttlerowej wskazują, że w nominalnej leksyce polskiej wśród wyodrębnionych 23 klas semantycznych nazwy ciała ludzkiego pod względem frekwencji zajmują wysokie trzecie miejsce ${ }^{4}$.

\section{Frazeologizmy somatyczne zawierające komponent KREW}

Komponent KREW także jest klasyfikowany jako nazwa części ciała (nomen anatomicum $)^{5}$. Michow zauważa, że analiza somatyzmów wskazuje, że istnieje związek między znaczeniem jednego ich elementu — nazwą części ciała a znaczeniem globalnym badanego związku frazeologicznego. Jednocześnie badaczka podkreśla, że właściwości części ciała zauważone i utrwalone w znaczeniach związków frazeologicznych najczęściej nie są naukowo sprawdzone i dowiedzione, lecz na ogół są to właściwości przypisywane im przez tradycję, wierzenia ludowe lub tzw. naiwną wiedzę o świecie. Michow wskazuje, że również o roli krwi istnieją potoczne sądy i przekonania (o różnym stopniu produktywności) ${ }^{6}$. Badaczka zauważa m.in., że we frazeologii

${ }^{2}$ Zob. S. Skorupka: Z zagadnień frazeologii. „Poradnik Językowy” 1953, z. 8, s. 10; A.M. Lewicki, A. Pajdzińska: Frazeologia. W: Wspótczesny język polski. Red. J. Bartmiński. Lublin 2001, s. 329.

${ }^{3}$ E. Michow: Z zagadnień frazeologii..., s. 82.

${ }^{4}$ Zob. D. Buttler: Kategorie semantyczne leksyki potocznej. W: Z zagadnień słownictwa współczesnego języka polskiego. Red. M. Szymczak. Wrocław 1978, s. 44.

${ }_{5}^{5}$ E. Michow: Polskie i butgarskie frazeologizmy somatyczne zawierajace komponent krew. „Kieleckie Studia Filologiczne” 1992, t. VI, s. 176.

${ }^{6}$ E. Michow: Z zagadnień frazeologii..., s. 82. 
krew ma związek z temperamentem, charakterem, emocjami człowieka, ma udział także w określeniu pochodzenia i cech wrodzonych. Podkreśla się także jej czerwoną barwę?

\section{Szkolne słowniki frazeologiczne}

Materiał zgromadzony $\mathrm{w}$ niniejszym artykule został wyekscerpowany z sześciu szkolnych słowników frazeologicznych wydanych po 2000 roku. Ze względu na cechy edytorskie — za Piotrem Żmigrodzkim — słowniki te należy uznać za publikacje małe lub średnie

1. Aleksandra Kubiak-Sokół, Elżbieta Sobol: Szkolny słownik frazeologiczny $P W N$. Warszawa 2007 (SPWN);

2. Katarzyna Głowińska: Szkolny słownik frazeologiczny. Warszawa 2009 (SG);

3. Wojciech Rzehak, Marzena Paw, Marcin Wawrzecki: Słownik związów frazeologicznych. Kraków 2005 (SZF);

4. Bernadeta Bodek, Monika Buława, Renata Brzozowska: Praktyczny słownik frazeologiczny. Red. Iwona Puchalska. Kraków 2004 (PSF);

5. Zuzanna Dominów, Marcin Dominów: Szkolny stownik frazeologiczny. Białystok 2005 (SDD);

6. Ewa Piotrowicz-Karmowska, Marek Karmowski: Szkolny stownik frazeologiczny. Warszawa 2005 (SKK).

Wyekscerpowane frazeologizmy somatyczne z komponentem KREW zestawiono w tabeli ${ }^{9}$.

${ }^{7}$ Zob. ibidem, s. 82, 86-87. Zob. także: Eadem: Polskie i butgarskie frazeologizmy somatyczne..., s. 183; Eadem: Studia nad frazeologia somatyczna języka polskiego i bułgarskiego. Kielce 2013, s. 107, 118-120, 123-131.

${ }^{8}$ Piotr Żmigrodzki proponuje, by ze względu na cechy edytorskie wyróżnić słowniki: wielkie (duże), średnie, małe i kieszonkowe. Zob. P. Żmigrodzki: Słowo - słownik - rzeczywistość. Z problemów leksykografii i metaleksykografii. Kraków 2008, s. 90.

${ }^{9} \mathrm{~W}$ zestawieniu w tabeli, dla przejrzystości oglądu, pominięto jednostki frazeologiczne odnotowane wyłącznie w jednym lub dwóch słownikach. 


\section{Frazeologizmy z komponentem KREW w szkolnych słownikach frazeologicznych}

Z sześciu wybranych szkolnych słowników frazeologicznych wyekscerpowano ponad sześćdziesiąt związków frazeologicznych z komponentem KREW. Liczną grupę stanowią jednak związki odnotowane wyłącznie w jednym ze słowników ${ }^{10}$, zwłaszcza w SPWN, zob.: Krew nabiega, napływa komuś do twarzy; krew ucieka, odplywa komuśs z twarzy; Coś burzy komuś, w kimś krew, coś wzburzyto (w kimś, czyjąś) krew; Krew w kimś zagrała; Do pierwszej krwi; Głos, zew krwi; Bez kropli krwi; Coś sptynęto, sptynie krwia; Coś ścina krew w żyłach; Komuś krew ścięła się w sercu; Krew komuś krzepnie, zastyga, ścina się, stygnie; Krew nie woda; Krew się polała; Krew zawrzała w kimś, komuś w żyłach; krew się w kimś zagotowała; Krew z mlekiem; Ktoś ma w żyłach czyjąś krew; w czyichś żyłach płynie czyjaś krew; Ktoś żadny krwi; Przypieczętować krwia; Rozlew, przelew krwi; Utoczyć sobie krwi dla kogoś, dla czegoś, za coś; dać sobie krew (z serca, spod serca) utoczyć dla kogoś, dla czegoś, za coś; Za cenę krwi; Zapłacić za coś (własna) krwią; Mróz ścina komuś krew w żyłach; Rozpalić komuś krew w żyłach; Krew, śmierć czyjaś spadnie na kogoś; Sprzedać drogo życie, krew itp.; Pławić się we krwi; Nie poskapić dla kogoś, dla czegoś (własnej) krwi; Ktoś by serce wyjąt z piersi (dla kogoś), utoczytby krwi z serca; Tonać we krwi; Topić coś we krwi; Unurzać ręce we krwi; Upuścić komuś (sobie) krwi; Ta zniewaga krwi wymaga, a także znacznie rzadziej w SDD, zob.: mieć zimna krew; zachować zimna krew; odzyskać zimna krew; człowiek z krwi $i$ kości; psuć czyjąś krew w znaczeniu 'dopuszczać do mezaliansu, zezwalać na wiązanie się ludzi z osobami z niższej sfery społecznej, politycznej lub ekonomicznej'11 oraz PSF, zob.: czystej krwi.

Kilka związków frazeologicznych odnotowano jedynie w dwóch słownikach, por.: Krew z krwi, z (czyjejś) kości (SPWN) / krew z krwi, kość z kości (SG); świeża krew (SPWN, SG); tracić / stracić zimna krew (SDD, SKK); do ostatniej kropli krwi (SPWN, SKK); goraca krew (PSF) / Goraca krew; ktoś goracej krwi (SPWN); Splamić ręce krwia, zbrodnia itp.; mieć krew na rękach (SPWN) / mieć krew na rękach (SDD); Przelać czyjąś krew (SPWN) / lać krew, przelewać krew (SZF) w znaczeniu 'zabić lub poważnie zranić kogoś'.

Jedynie kilka frazeologizmów somatycznych z komponentem KREW odnotowano we wszystkich sześciu analizowanych słownikach szkolnych, zob.: coś idzie (komuś) jak krew z nosa; mieć (coś) we krwi; napsuć (komuś) krwi / psuć komuś krew; z krwi i kości; także tylko kilka w pięciu z sześciu słowników, por.:

${ }^{10} \mathrm{~W}$ artykule stosuje się oryginalną pisownię związków frazeologicznych, zastosowaną w poszczególnych słownikach.

11 SDD, s. 95. 
błękitna krew; krew uderza / uderzyła komuś do głowy; (coś) mrozi (komuś) krew w żłach / mrożacy krew w żyłach; (coś) weszło (komuś) w krew; zimna krew; z zimna krwiq. Zestawienia frekwencyjne pokazują, jak bardzo zróżnicowane są decyzje autorów szkolnych słowników tego samego typu pod względem selekcji jednostek frazeologicznych.

\section{Związki frazeologiczne z komponentem KREW w makrostrukturze szkolnych słowników frazeologicznych}

Najwięcej, bo aż ponad 50 frazeologizmów somatycznych z komponentem KREW wraz z ich wariantami odnotowano w SPWN. Należy także zauważyć, że wiele związków występuje wyłącznie w SPWN, nie odnajdziemy ich w żadnym z pozostałych analizowanych słowników szkolnych. SPWN jest wyborem materiału z Wielkiego słownika frazeologicznego PWN z przysłowiami ${ }^{12}$. Niestety, dużą wadą SPWN jest notacja związków frazeologicznych tylko w jednym miejscu w makrostrukturze, co nie sprzyja poszukiwaniu konkretnych frazeologizmów ${ }^{13}$. Rozwiązanie dotyczy jedynie słownika szkolnego, w którym — by zmniejszyć objętość - usunięto stosowane w Wielkim słowniku odsyłacze do haseł z definicjami frazeologizmów lub przysłów. Przykładowo, związki frazeologiczne: Coś idzie komuś jak krew z nosa; Krew uderzyła komuś do głowy, do mózgu; Krew z krwi, kość z (czyjejś) kości; Z krwi i kości; Cośśsina krew w żytach; Komuś krew ścięta się w sercu; Krew zawrzała w kimś, w czyichś żyłach; Ktoś ma $w$ żyłach czyjąś krew; w czyichś żyłach plynie czyjaś krew; Splamić ręce krwia, zbrodnia itp.; Mieć krew na rękach odnotowano tylko w jednym miejscu w makrostrukturze słownika szkolnego. Somatyzmy, które poza komponentem KREW zawierają także nazwy innych części ciała, zostały jednak odnotowane tylko raz w słowniku — w haśle KREW, nie zaś np. w hasłach: NOS, GŁOWA, MÓZG, KOŚĆ, ŻYŁA itd.

Najbardziej rozbudowany system odsyłaczy został zastosowany w SG: odesłania do tego samego frazeologizmu z komponentem KREW możemy znaleźć w trzech, a nawet czterech miejscach w słowniku, co właściwie eliminuje trudności w odszukaniu właściwego frazeologizmu, przy jednoczesnej oszczędności miejsca, zob.: błękitna krew (pełny opis w haśle: KREW, odsyłacze: BŁĘ-

12 Wielki słownik frazeologiczny PWN z przysłowiami. Oprac. A. Kłosińska, E. Sobol, A. Stankiewicz. Warszawa 2011.

${ }^{13}$ Por. G. Dziamska-Lenart: Kryteria oceny szkolnych słowników frazeologicznych. W: Istnieć w kulturze. Red. M. Święcicka, D. Jastrzębska-Golonka, A. Rypel. Bydgoszcz 2010, s. $287-288$. 
KITNY, CZESŚCI CIAŁA/ KREW, KOLORY/BŁĘKITNY); coś idzie jak krew z nosa (pełny opis w haśle: KREW, odsyłacze: CZĘŚCI CIAŁA/ KREW, CZEŚCI CIAŁA/ NOS, NOS); mrożacy krew w żyłach (pełny opis w haśle: KREW, odsyłacze: CZĘŚSCI CIAŁA/ KREW, CZĘŚCI CIAŁA/ ŻYŁA, ŻYŁA); z krwi $i$ kości (pełny opis w haśle: KREW, odsyłacze: CZĘ́ŚCI CIAŁA/ KREW, CZEŚSCI CIAŁA/ KOŚĆ, KOŚĆ); krew z krwi, kość z kości (pełny opis w haśle: KREW, odsyłacze: BIBLIA, CZĘŚCI CIAŁA/ KREW, CZĘŚSI CIAŁA/ KOŚĆ, KOŚĆ). Z konsekwentnie realizowanej strategii notacji można wnioskować, że podobnie jak w SPWN, autorka SG także uważa komponent KREW jako najsilniejszy dla frazeologizmów somatycznych zawierających więcej niż jedną nazwę części ciała.

Dużą zaletą SG, zwłaszcza w praktyce szkolnej, jest również częsta notacja kilku zróżnicowanych przykładów użycia związku frazeologicznego; np. trzy przykłady użycia frazeologizmów: krew uderzyła komuś do głowy / krew uderza komuś do głowy; krew kogoś zalewa / krew kogoś zaleje; krew z krwi, kość z kości; mrożacy krew w żyłach; ktoś napsut komuś krwi; świeża krew; coś weszło komuś w krew; z krwi i kości, a nawet cztery egzemplifikacje, zob.: zimna krew; ktoś ma coś we krwi:

- ktoś ma coś we krwi 'coś jest czyjąś stałą, niezbywalną, czasem odziedziczoną cechą' o Zamiłowanie do porządku ma we krwi. Nie spocznie, póki wszystko nie będzie leżało na swoim miejscu. Nasz region bogaty jest w talenty. Przecież wszyscy górale śpiewają i grają. Mają to we krwi. (TP 7/98, B. Zalot) o - To wielki talent mówi Mirosław Piskorz, jej trener z klubu sportowego Orzeł w Wierzbicy. Jest bratanicą Włodka Zawadzkiego, mistrza olimpijskiego z Atlanty. Zapasy i wolę walki ma we krwi, tak jak on. (GW 136/98, I. Bednarz) o To jedyny kraj, gdzie po ubraniu nie odróżni się od razu robotnika od zarządzającego firmą. Zwłaszcza, jeśli spotka się ich na deptaku w niedzielne popołudnie. Potrzebę piękna mają we krwi, co widać na każdym kroku, w każdej dziedzinie życia. (MRzP 29/98, P. Raksa) 
W PSF odnotowano trzynaście somatyzmów z komponentem KREW wraz z ich wariantami, a także zastosowano system odsyłaczy z dodatkowymi, charakterystycznymi dla słownika rozwiązaniami — odesłania do frazeologizmów bliskoznacznych, dodatkowa notacja niektórych frazeologizmów na końcu słownika (alfabetyczny indeks czasowników). Warto zauważyć, że jeśli frazeologizm został odnotowany w kilku miejscach słownika, jego pełny opis znajdujmy w haśle: KREW; zob.: coś idzie jak krew z nosa (pełny opis w haśle: KREW, odsyłacz: NOS; IŚĆ — Indeks czasownikowy); zimna krew (pełny opis w haśle: KREW, odsyłacz: ZIMNY); z krwi i kości (pełny opis w haśle: KREW, odsyłacz: KOŚĆ); goraca krew (pełny opis w haśle: KREW, odsyłacz: GORĄCY); czystej krwi (pełny opis w haśle: KREW, odsyłacz: CZYSTY). Czasem jednak zastosowany system odsyłaczy jest zawodny. Wyrażenie błękitna krew odnotowano w haśle BŁĘKITNY z odsyłaczem do hasła KREW, gdzie znajdziemy frazeologizmy: $w$ czyichś żyłach płynie błękitna krew; ktoś ma w żyłach błękitna krew wraz z opisem leksykograficznym (definicją znaczenia i jednym przykładem użycia: „Zawsze z dumą podkreślał, że jest nie byle kim, i że w jego żyłach płynie błękitna krew"14). W takiej sytuacji wydaje się zasadne, aby odnotować wyrażenie błękitna krew również w haśle: KREW, a także, by rozważyć notację egzemplifikacji ilustrującej przykład użycia każdego z wariantów. Podobnie frazeologizm coś mrozi (komuś) krew w żyłach odnotowano wraz z pełnym opisem w haśle: KREW, natomiast coś mrozi (komuś) krew w żyłach; mrożacy krew $w \dot{z} y ł a c h w$ haśle ŻYŁY. Rozwiązanie to wydaje się tym bardziej nieudanym zabiegiem, że jako przykład użycia w haśle KREW odnotowano wariant mrożacy krew w żylach:

coś mrozi (komuś) krew w żyłach — coś wywołuje przerażenie;

No więc kiedyś tam, jakiś czas temu, ktoś usłyszał potworny krzyk ze środka zamku. Taki krew w żyłach mrożący.

(J. Chmielewska, Ślepe..., s. 185)

(PSF, KREW)

Cennym natomiast w praktyce dydaktycznej i odróżniającym od innych słowników jest rozwiązanie zastosowane w PSF, polegające na wskazywaniu frazeologizmów bliskoznacznych w słowniku, zob.: napsuć komuś krwi odnotowano jako frazeologizm bliskoznaczny przy aż czterech innych frazeologizmach w obrębie makrostruktury słownika, por.: dawać, dać komuś w kość; dać komuś tupnia; zalewać, zalać (komuś) sadta za skórę; dawać, dać się komuś we znaki; frazeologizm: z krwi i kości por. czystej krwi i odwrotnie — przy związku czystej krwi odnotowano por. z krwi i kości.

\footnotetext{
${ }_{14}$ PSF, s. 102.
} 
W SZF odnotowano trzynaście związków frazeologicznych z komponentem KREW wraz $\mathrm{z}$ ich wariantami. W słowniku zastosowano znacznie mniej rozbudowany system odsyłaczy niż w SG i PSF. Autorzy SZF odnotowują także zaledwie jeden przykład użycia związku. Właściwie nadrzędną strategią jest stosowanie w słowniku systemu odsyłaczy i notacja pełnego opisu jednostki $\mathrm{w}$ jednym haśle, realizacja tego zamierzenia nie jest jednak konsekwentnie realizowana. Część frazeologizmów odnotowano w podobny sposób jak w innych słownikach z odsyłaczami, por.: mieć w żyłach błękitna krew; $w$ czyichś żyłach płynie błękitna krew (pełny opis w haśle: KREW, odsyłacz: ŻYŁY); coś idzie jak krew z nosa (pełny opis w haśle: KREW, odsyłacz: NOS); krew uderza komuś do głowy (pełny opis w haśle: KREW, odsyłacz: GLOWA); coś mrozi krew $w$ żyłach (pełny opis w haśle: KREW, odsyłacz: ŻYŁY). Są jednak frazeologizmy, do których nie zastosowano systemu odsyłaczy, por.: mieć coś we krwi; napsuć (psuć) komuś krwi; wejść (komuś) w krew; z zimna krwia; z krwi i kości; krew się w kimś burzy (gotuje) — wszystkie frazeologizmy odnotowano tylko w jednym miejscu w makrostrukturze SZF, w haśle KREW.

Zestawienie zastosowanych w SPWN, SG, PSF i SZF rozwiązań wobec notacji związków frazeologicznych z komponentem KREW pozwala zauważyć, że autorzy publikacji na ogół uznali go jako najsilniejszy dla większości związków frazeologicznych z tym komponentem. Co szczególnie ciekawe, dotyczy to także frazeologizmów zawierających inne nazwy części ciała.

W SDD odnotowano łącznie siedemnaście somatyzmów z komponentem KREW, większość z nich w kilku miejscach makrostruktury. Autorzy na ogół zamieszczają związek frazeologiczny pod wszystkimi jego komponentami autosemantycznymi wraz z pełnym opisem (definicja znaczenia, schemat składniowy), np.: związek frazeologiczny krew uderza do glowy zamieszczono w trzech miejscach słownika (pod hasłami: KREW, GŁOWA, UDERZYĆ); związek mrożacy krew w żylach (pod hasłami: KREW, MROŻĄCY, ŻYŁA); mieć krew na rękach (pod hasłami: KREW, MIEĆ, RĘKA). Realizacja przyjętej strategii nie jest jednak w pełni konsekwentna, por.: stracić zimna krew (pod hasłami: KREW, STRACIĆ, ZIMNY); zachować zimna krew (pod hasłami: KREW, ZACHOWAĆ, ZIMNY); ale: odzyskać zimna krew (pod hasłami: KREW, ODZYSKAĆ); tracić zimna krew (tylko pod hasłem: TRACIĆ); mieć zimna krew (tylko pod hasłem: MIEĆ).

W obrębie makrostruktury słownika na ogół znajdujemy identyczną definicję tego samego frazeologizmu, odnotowaną w kilku miejscach. Można znaleźć także bliskoznaczne, ale nie identyczne definicje tego samego związku frazeologicznego, por.:

mieć krew na rękach »być sprawcą czyjejś śmierci lub przyczynić się do niej« (KREW) 
mieć krew na rękach »być sprawcą czyjejś śmierci lub przyczynić się do niej« (MIEĆ)

mieć krew na rękach »być sprawcą czyjejś śmierci lub przyczynić się do niej« (RĘKA)

ale:

krew uderza do głowy »ktoś ulega silnym emocjom, traci panowanie nad sobąu (KREW)

krew uderza do głowy »ktoś ulega silnym emocjom, traci panowanie nad sobą" (GŁOWA)

krew uderza do głowy »ktoś ulega silnym emocjom, traci panowanie nad sobą, złości się, wścieka, irytuje, wpada w gniew« (UDERZYĆ)

Notacja w kilku miejscach słownika tych samych informacji, w SDD: schematu składniowego i definicji znaczenia sprawia pozory większej objętości słownika, jednocześnie wpływa na mniejszą rzeczywistą liczbę odnotowanych jednostek słownikowych.

Odróżniające się na tle innych słowników strategie notacji zastosowali autorzy SKK. W tym słowniku jako jedynym związki frazeologiczne nie są uporządkowane w układzie gniazdowym. Hasłami są same związki frazeologiczne w układzie alfabetycznym, poza tym w SKK zamieszcza się także hasła odsyłaczowe (z reguły człon rzeczownikowy danego frazeologizmu). W SKK odnotowano jedenaście związków frazeologicznych z komponentem KREW wraz z ich wariantami. Większość $z$ frazeologizmów odnotowano pod hasłem tożsamym ze związkiem frazeologicznym (co jest kontrowersyjnym rozwiązaniem, biorąc pod uwagę wielopostaciowość frazeologizmów, ich wariantywność). Jednocześnie do większości z nich znajdziemy odesłanie w haśle odsyłaczowym KREW, zob.: błękitna krew; iść jak krew z nosa; mieć [coś] we krwi; napsuć [komuś] krwi; psuć [komuś] krew; wejść [komuś] w krew; zimna krew; tracić / stracić zimna krew; z zimna krwia; z krwi i kości, rzadziej w innym, por.: do ostatniej kropli krwi w haśle odsyłaczowym: KROPLA; z krwi $i$ kości w hasłach odsyłaczowych: KOŚĆ i KREW. Najczęściej autorzy odnotowali dwa przykłady zastosowania każdego z frazeologizmów z komponentem KREW, wyjątek stanowi frazeologizm z krwi $i$ kości, który zilustrowano aż trzema zróżnicowanymi przykładami użycia, zob.:

z krwi i kości «taki, jaki powinien

być; autentyczny, z prawdziwego

zdarzenia»: Był artystą z krwi

i kości, żyjącym sztuką i dla sztuki.

Książę — następca tronu - 
chciał być królem z krwi

i kości, a nie malowanym. Bohater

reportażu jest człowiekiem

z krwi i kości ze wszystkimi

wadami i zaletami.

(SKK, Z KRWI I KOŚCI)

\section{Notacja związków frazeologicznych z komponentem KREW nacechowanych stylistycznie}

Wśród odnotowanych frazeologizmów z komponentem KREW znalazły się także związki nacechowane stylistycznie (książkowe, żartobliwe, potoczne). Wydaje się, że jest to rozwiązanie dopuszczalne w słownikach szkolnych, wyłącznie jednak jeśli jednostki te są oznaczone stosownymi kwalifikatorami stylistyczno-pragmatycznymi. Użytkownicy języka, a tym bardziej uczniowie, nie rozróżniają bowiem słowników o charakterze normatywnym od rejestrujących i jednostki odnotowane w słownikach traktują jako usankcjonowane normą ${ }^{15}$.

Rozwiązania zastosowane w szkolnych słownikach frazeologicznych, dotyczące notacji i oznaczania jednostek nacechowanych stylistycznie, są zróżnicowane ${ }^{16}$. We wszystkich poddanych ekscerpcji słownikach odnotowany został potoczny związek frazeologiczny: (coś) idzie (komuś) jak krew z nosa. W SPWN związek ten odnotowano w haśle KREW i oznaczono kwalifikatorem pot. (potoczny); w SG frazeologizm odnotowano w czterech miejscach słownika, jednak tylko w jednym miejscu — w haśle KREW — opatrzono go kwalifikatorem pot.; także w PSF kwalifikator pot. umieszczony został tylko w haśle KREW. Z kolei w słownikach SZF, SDD i SKK w żadnym z miejsc, w których pojawia się ten frazeologizm, nie oznaczono go jako jednostki nacechowanej. Kolejny frazeologizm: krew kogoś zalewa, odnotowany jest w trzech słownikach: w SPWN - (Nagła, zła, jasna) krew kogoś zalewa w haśle: KREW z kwalifikatorem pot.; w SDD — krew zalała w hasłach: KREW i ZALAĆ bez kwalifikatorów; w SG - krew kogoś zalewa na liście tematycznej CZĘŚCI CIAŁA/

${ }^{15}$ Zob. K. Mosiołek-Kłosińska, A. Ciesielska: Słownik frazeologiczny dla młodzieży koncepcja leksykograficzna. W: Problemy Frazeologii Europejskiej. T. IV. Red. A.M. Lewicki. Lublin 2001, s. 37.

${ }^{16}$ Zob. G. Dziamska-Lenart: Kryteria oceny szkolnych słowników frazeologicznych. W: Istnieć w kulturze..., s. 289-291. 
KREW bez kwalifikatora, natomiast w haśle: KREW odnotowano krew kogoś zalewa / krew kogoś zaleje z kwalifikatorem pot.

$\mathrm{W}$ dwóch słownikach odnotowano frazeologizm o proweniencji biblijnej: krew z krwi, kość z (czyjejś) kości. W SPWN występuje on w haśle KREW i oznaczony jest kwalifikatorem podn. (podniosły), natomiast w SG odnotowano go w aż pięciu miejscach, lecz tylko w jednym miejscu, w haśle KREW, oznaczono kwalifikatorem książk. (książkowy).

W dwóch słownikach (SZF, SDD) nieoznaczenie związku frazeologicznego kwalifikatorem stylistyczno-pragmatycznym wynika z braku kwalifikatorów we wszystkich artykułach hasłowych, mimo notacji jednostek substandardowych. W praktyce szkolnej takie rozwiązanie tym bardziej należy uznać za mankament publikacji.

\section{$* * *$}

W podsumowaniu artykułu należy wskazać na najczęstsze mankamenty, niekonsekwencje i usterki w notacjach frazeologizmów z komponentem KREW w szkolnych słownikach frazeologicznych. Są to:

— na ogół mała ogólna liczba jednostek w słownikach (czasem przy jednoczesnej notacji w słowniku szkolnym jednostek potocznych i wulgarnych);

- bardzo zróżnicowany repertuar zamieszczonych związków frazeologicznych z komponentem KREW w poszczególnych słownikach szkolnych;

- niekonsekwentna notacja jednostek frazeologicznych i ich wariantów w makrostrukturze słowników;

- niekonsekwentna notacja definicji znaczenia frazeologizmu w makrostrukturze słownika;

- wybiórcze stosowanie lub brak kwalifikatorów stylistycznych lub jakiejkolwiek informacji o nacechowaniu stylistycznym notowanych jednostek.

Słowniki szkolne są publikacjami z zasady o mniejszej objętości, materiał leksykalny z konieczności jest więc w nich w pewien sposób ograniczony i wynika z subiektywnego wyboru autorów. Należy jednak dołożyć wszelkich starań, by był to wybór uwzględniający realne potrzeby odbiorców publikacji. Warto zatem, by autorzy szkolnych słowników frazeologicznych nie tylko byli znawcami frazeologii i frazeografii, ale także znali potrzeby językowe współczesnych uczniów. 


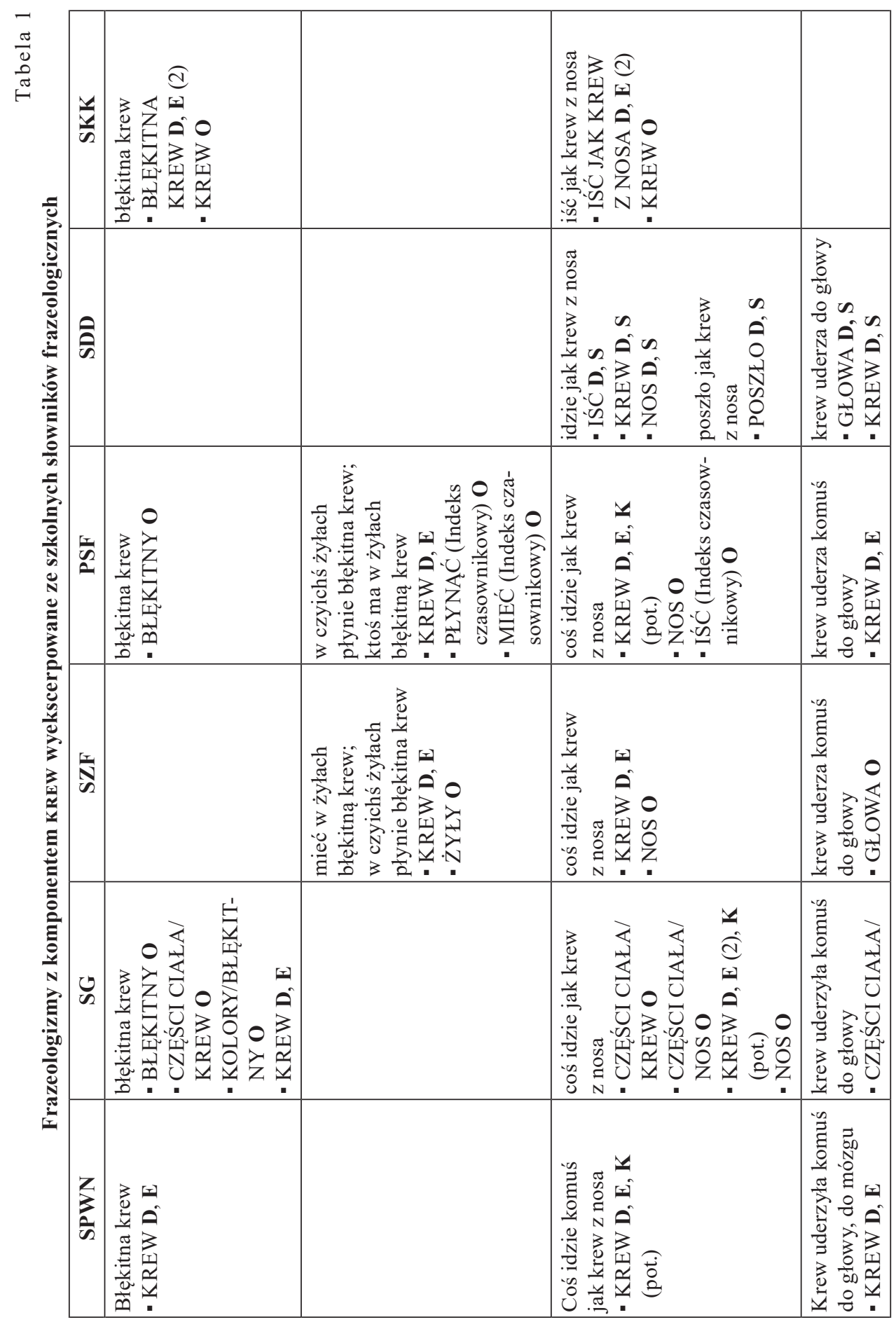




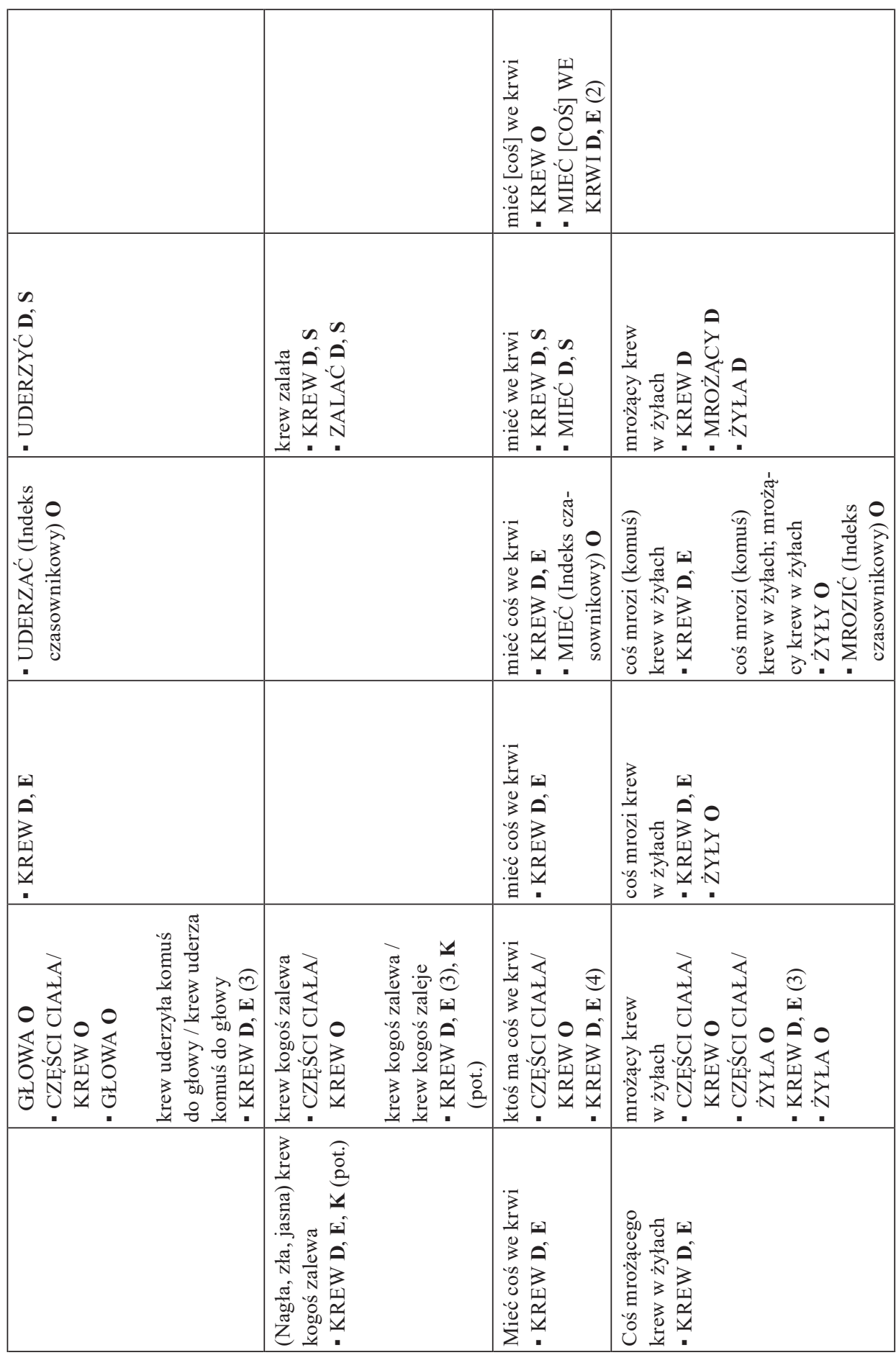




\begin{tabular}{|c|c|c|c|c|c|}
\hline$\frac{y}{a}$ & 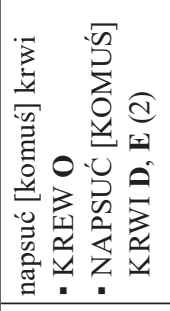 & 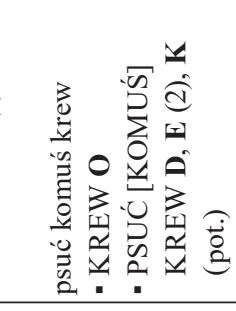 & 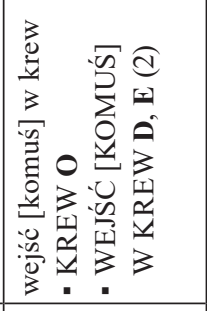 & 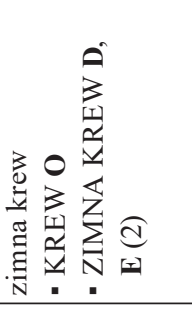 & 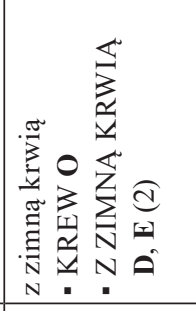 \\
\hline ڤิ & 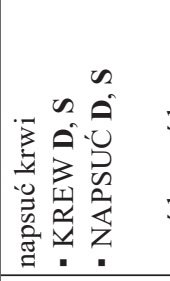 & 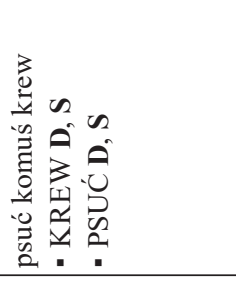 & 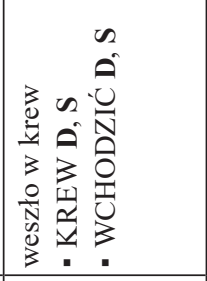 & & 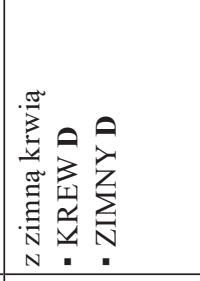 \\
\hline $\begin{array}{l}\mathbf{L} \\
\mathscr{L}\end{array}$ & 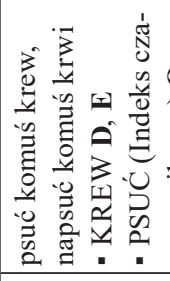 & 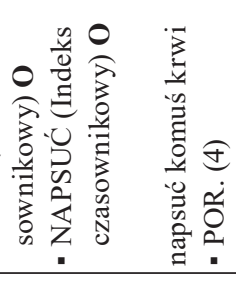 & & 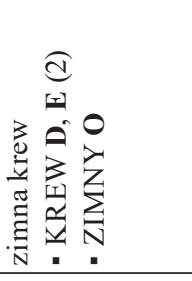 & \\
\hline 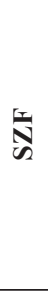 & 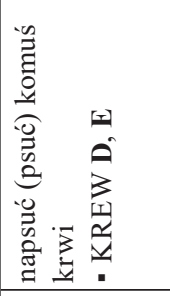 & & 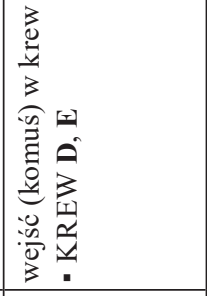 & 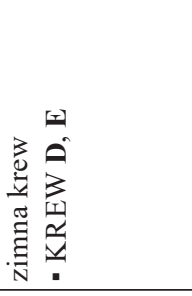 & 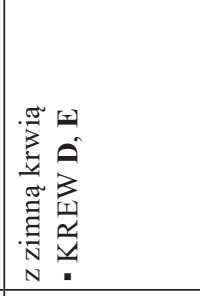 \\
\hline U. & 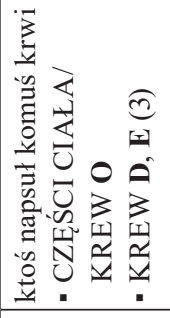 & & 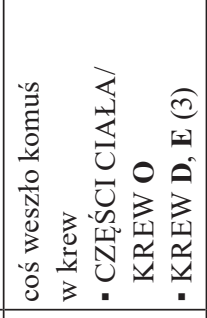 & 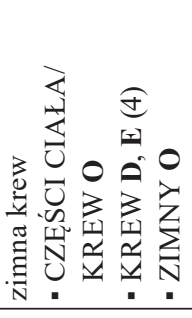 & 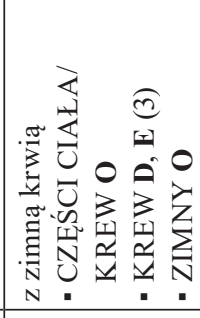 \\
\hline 宬 & 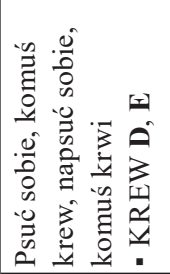 & & 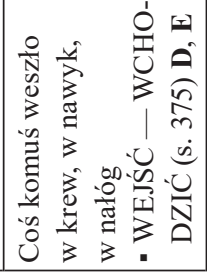 & 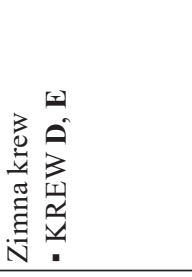 & 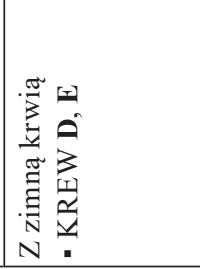 \\
\hline
\end{tabular}




\begin{tabular}{|c|c|c|}
\hline 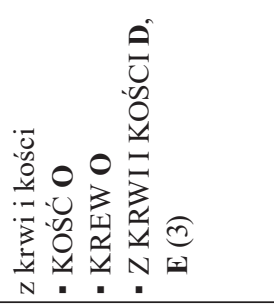 & & \\
\hline 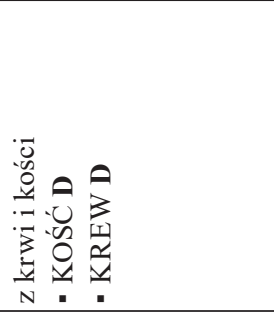 & 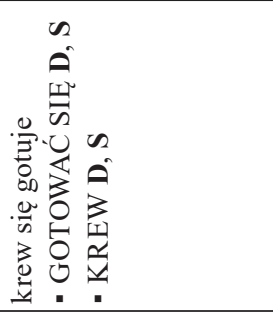 & \\
\hline 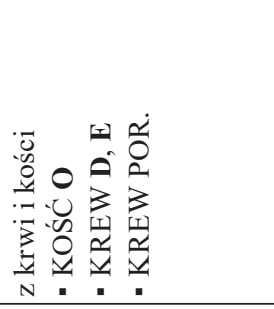 & 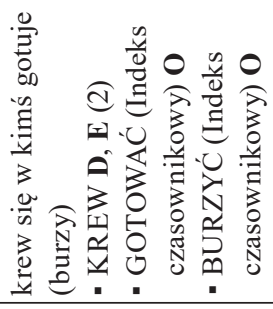 & 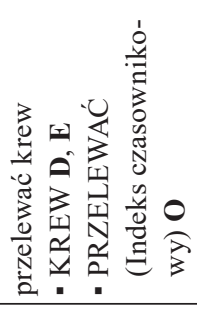 \\
\hline 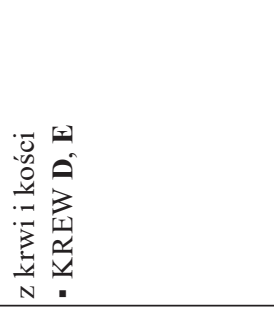 & 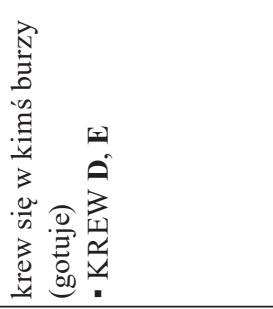 & 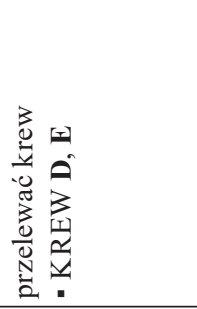 \\
\hline 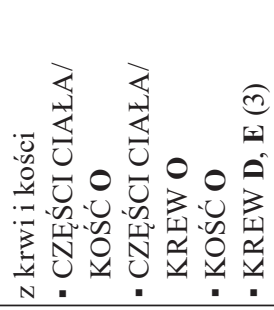 & & \\
\hline 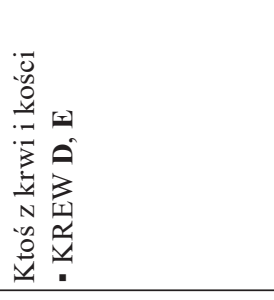 & 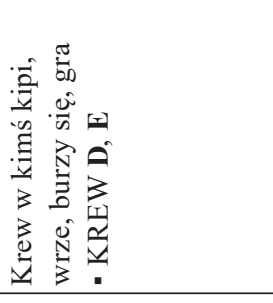 & 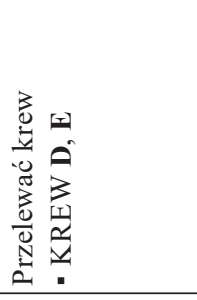 \\
\hline
\end{tabular}




\section{Bibliografia}

Buttler D.: Kategorie semantyczne leksyki potocznej. W: Z zagadnień słownictwa współczesnego języka polskiego. Red. M. Szymczak. Wrocław 1978.

Dziamska-Lenart G.: Kryteria oceny szkolnych słowników frazeologicznych. W: Istnieć w kulturze. Red. M. Święcicka, D. Jastrzębska-Golonka, A. Rypel. Bydgoszcz 2010.

Krawczyk-Tyrpa A.: Frazeologia somatyczna w gwarach polskich. Wrocław 1987.

Lewicki A.M., Pajdzińska A.: Frazeologia. W: Wspótczesny język polski. Red. J. Bartmiński. Lublin 2001.

Michow E.: Polskie i butgarskie frazeologizmy somatyczne zawierające komponent krew. „Kieleckie Studia Filologiczne" 1992, t. VI.

Michow E.: Studia nad frazeologia somatyczna języka polskiego i butgarskiego. Kielce 2013.

Michow E.: Z zagadnień frazeologii: związi frazeologiczne zawierające nazwy czéści ciała. Cz. I. „Język Polski w Szkole dla Klas IV_-VIII” 1988/1989, z. 1.

Mosiołek-Kłosińska K., Ciesielska A.: Słownik frazeologiczny dla młodzieży — koncepcja leksykograficzna. W: Problemy Frazeologii Europejskiej. T. IV. Red. A.M. Lewicki. Lublin 2001.

Skorupka S.: Z zagadnień frazeologii. „Poradnik Językowy” 1953, z. 8.

Tyrpa A.: Frazeologia somatyczna: zwiazki frazeologiczne o znaczeniach motywowanych cechami części ciała w gwarach polskich. Łask 2005.

Żmigrodzki P.: Stowo - stownik — rzeczywistość. Z problemów leksykografii i metaleksykografii. Kraków 2008.

\section{Słowniki}

Bodek B., Buława M., Brzozowska R.: Praktyczny słownik frazeologiczny. Red. I. Puchalska. Kraków 2004.

Dominów Z., Dominów M.: Szkolny stownik frazeologiczny. Białystok 2005.

Głowińska K.: Szkolny stownik frazeologiczny. Warszawa 2009.

Kubiak-Sokół A., Sobol E.: Szkolny słownik frazeologiczny PWN. Warszawa 2007.

Piotrowicz-Karmowska E., Karmow ski M.: Szkolny słownik frazeologiczny. Warszawa 2005.

Rzehak W., Paw M., Wawrzecki M.: Stownik zwiazków frazeologicznych. Kraków 2005.

Wielki słownik frazeologiczny PWN z przysłowiami. Oprac. A. Kłosińska, E. Sobol, A. Stankiewicz. Warszawa 2011. 